\title{
Denise Riley
}

\section{There is an old fiction of reliability}

is a weather presence, is a righteousness

is arms in cotton

this is what stands up in kitchens

is a true storm shelter

$\&$ is taken straight out of colonial history, master \& slave

arms that I will not love folded nor admire for their 'strength'

linen that I will not love folded but will see flop open

tables that will rise heavily in the new wind \& lift away,

bearing their precious burdens

of mothers who never were, nor white nor black

mothers who were always a set of equipment and a fragile balance mothers who looked over a gulf through the cloud of an act \&

at times speechlessly saw it

inside a designation there are people permanently startled to bear it, inside the kitchens there is realizing of tightropes

the not-me against sociology

milk, if I do not continue to love you as deeply and truly as you want

that is us in the mythical streets again.

and need

support, support.

the houses are murmuring with many small pockets of emotion on which spongy ground adults' lives are being erected and paid for while their feet and their children's feet are tangled around daily

like those of fen larks in the fine steely wires which run to \& fro between love \& economics affections must not support the rent

I. neglect. the house. 